\title{
Internal Branding and the Competitive Performance of Private Universities in Ghana
}

\author{
- Amegbe Hayford
}

\begin{abstract}
The objective of this paper is in three fold. First, to examine the inter-relationship between internal branding and performance of private universities. Second, to examine customer-based brand equity $(\mathrm{CBBE})$ antecedents in predicting the performance of private universities. Third, to examine the effect of internal branding on the performance of private universities when brand loyalty levels are high among students. The sample comprises 213 male and 234 female students studying at various private universities in the Greater Accra Region of Ghana. In order to have fair representation of students from all levels of classification from all the private universities in Accra, convenience sampling was purposefully used to collect data from undergraduate students in the private universities sampled. The result of the study indicated that the dimensions of brand equity and private universities' performance are positively related. The regression analyses indicate that there is a positively related predictive power of private universities performance by brand association and brand loyalty. However, the study did not find brand awareness and perceived quality to be positively related. The conclusion of the study is that the performance of private universities' and brand equity depends on the high loyalty among students.
\end{abstract}

Key words: Internal Branding, Brand Equity, Performance, and Private Universities

JEL Classification: M31

\section{INTRODUCTION AND BACKGROUND}

The demand for higher education in Ghana is high due to dramatic increase in population and net immigration. To the extent that state-funded (public) universities have to turn away a large number of applicants each academic year; leading to a backlog of potential students. Competition for admission to public universities is very keen. The numbers of qualified applicants for academic programmes far exceed the available vacancies; leading to only a few applicants with strong aggregate entry scores being admitted annually. As pointed out by Oduro and Senadza (2004), on the average, only forty-nine percent of qualified applicants gain admission to the public universities creating a demandsupply gap of fiftyone percent every year. This situation has led to the establishment of private universities in the country to augment access to tertiary education in Ghana. Today, the private sector is the fast growing segment in higher education in Ghana.

As of April 2015, the National Accreditation Board (NAB), the body mandated by Parliament to regulate and accredit institutions of higher education in Ghana, has accredited 57 private universities and, more others are in the process of being accredited. The situation has led to increased competition for students among the private universities and their public counterparts. This calls for strong branding to be ahead of the competition and also attract appreciable students' numbers. Pinar, Trapp, Girard, and Boyt (2011) indicated that the role of brand management 
has been elevated to a new level of importance in today's global marketplace. They further observed that brand management are powerful assets, brands represent the essence of a company; therefore, they must be developed and managed carefully.

Kotler and Keller (2006) indicated that brands represent consumers' perceptions and feelings about a product (service) and its performance and that the real value of a strong brand is its ability to capture customer preference and loyalty. Branding efforts are no longer limited to "consumer products." Firms in various service industries have been trying to utilize branding strategies to build stronger brands (Pinar, Trapp, Girard, and Boyt, 2011). In this regard, institutions of higher learning are not exceptions; they have also realized the need to develop sustainable brand strategies. In fact, branding has increasingly become a strategic imperative for universities and other post-secondary educational institutions to develop meaningfully differentiated brands to communicate their strengths (Jevons, 2006).

According to Preez and Bendixen (2015), there is a significant body of research illustrating the importance and benefits of internal branding. They indicated that in the view of Gummeson (1987), staff must be well acquainted with the "mission, goals and strategies" of an organization in order to deliver at the "moment of truth". Berry (2000) states "service providers make or break a brand (they) turn a marketer articulated brand into a customer-experienced brand". Schultz and de Chernatony (2002) contend that organizations rely on employees to deliver the brand promise. A customer's first experience of a brand is frequently influenced by the job behavior and performance of frontline employees (de Chernatony et al., 2003). De Chernatony and Cottam (2006) describe "a brand ethos" where "employee behavior is automatically based upon the brand" (p. 626). Punjaisri and Wilson (2007) write internal branding not only influences "on brand" performance "but also influences attitudes employees have toward the brand which [...] affects employee performance". Morhart et al. (2009) contend that "Customers perceptions of a service brand depend highly on the behavior of front line staff".

Due to the increasingly complex and highly competitive nature of private universities among private universities in Ghana, it is important to study whether the building of brand equity significantly impacts on the performance of private universities to warrant attention (in terms of resource allocation) from managers and owners of private universities. This study uses the customer-based brand equity (CBBE) model (i.e., brand awareness, loyalty, association, and perceived quality), as described by Aaker (1991) to assess the performance of private universities in Ghana from the perspective of undergraduate students. The objective of this study is three fold. First, to examine the inter-relationship between the level of internal branding and performance of private universities. Second, to examine the extent of the antecedents of brand equity (brand awareness, brand association, perceived quality, brand loyalty) in predicting the performance of private universities performance in Ghana. Third, to examine the effect of internal branding on the performance of private universities when the level of brand loyalty is high. 


\section{LITERATURE REVIEW}

\subsection{Brand equity}

The definition of brand equity can be approached from the perspective of investors, manufacturers, retailers or consumers. Retailers and manufacturers are usually concerned with the cash flow and strategic implications of brand equity, while investors concern themselves with value in terms of finances so as to treat it as an asset and include it in the firm's balance sheet (Myers, 2003; Keller, 1993). According to Keller (2003), "brand equity [is] the differential effect that brand knowledge has on consumer response to the marketing of the brand". Therefore, it is important for the brand to provide some value to customers in order for it to have a high equity level. This is because the power of a brand is determined by what customers learn of it over time. It also includes what they have felt, seen, or heard about the brand (Keller, 2003).

Aaker (1991) and Keller (1993) developed the foundation for consumer-based brand equity research. From a cognitive psychology approach, Aaker (1991) defines brand equity as "a set of brand assets and liabilities linked to a brand, its name and symbol that add to or subtract from the value provided by a product or service to a firm and/or to that firm's customers". These assets are brand awareness, perceived quality, brand associations, brand loyalty and other proprietary assets. Keller (1993) develops an alternative view and defines the concept of consumer-based brand equity as the differential effect of brand knowledge on consumer response to the marketing of the brand. Following these two approaches, this study uses a consumer-based brand equity measure that consists of four key constructs: brand awareness, perceived quality, brand associations, and brand loyalty and examines these on consumers' willingness to pay price premiums, consumers' attitude towards brand preference and purchase intention These brand equity dimensions are widely accepted and used by numerous researchers (e.g. Yoo et al., 2000; Kim et al., 2003; Pappu et al., 2005; Lee \& Back, 2010; Pike et al., 2010; Kim \& Hyun, 2011). For the purpose of this study, the construct described by Aaker (1991) for measuring consumer-based brand equity which includes; perceived quality, brand awareness, brand associations, and brand loyalty are used to measure the concept of overall university brand equity. These constructs are discussed in detail below.

\subsubsection{Brand Awareness}

Brand awareness is the first step to creating brand equity. This dimension refers to whether consumers can recall or recognise a brand and is related to the strength of a brand's presence in consumers' minds (Aaker, 1996). Perceived quality and brand associations are also two key dimensions of brand equity. Perceived quality refers to the perception of the overall quality or superiority of a product or service relative (Keller, 2003), while brand associations are the concepts that have links to the brand name in consumer memory (Keller \& Lehmann, 2006).

Brand awareness involves linking the brand to different associations in memory (Keller, 2003). Therefore, consumers must first be aware of a brand to later have a set of brand associations (Aaker, 1991). Brand awareness affects the formation and the strength of brand associations, including perceived quality (Keller, 1993; Pitta \& Katsanis, 1995; Keller \& Lehmann, 2003; Pike et al., 2010). 


\subsubsection{Perceived quality}

Perceived quality refers to the judgement or perception about the superiority of the product compared to others in the same category or close substitutes. It is the ability of a product to offer the necessary level of satisfaction better than other alternatives. As explained by Baldauf et al. (2003), the quality of a product is a significant resource that enables the firm to achieve competitiveness. When the firm creates a brand, they need to communicate the essence of the brand with the aim of positioning it in the minds of the audience in the marketplace so as to match the characteristics of the brand to the needs and expectations of the consumers. According to Hamann et al. (2007), branding contributes greatly to providing security and assuring customers of the quality of products. The development of powerful brands in a market arises from consistently providing a compelling experience to customers. The experience is achieved through the distribution channels, the product on offer, physical environment, employee behaviour and brand communication. These factors largely contribute to making the brand tangible to consumers (Abimbola \& Vallaster, 2007). Having a high-quality brand is not only a prerequisite to being competitive in a market; it enables also the company that owns the brand to become attractive in the marketplace (Urde, 1994). The service encounter provided by the firm to its customers serves as the strongest impression of quality of the brand; hence, every interaction between the firm and its customers affects the brand image (de Chernatony \& Drury, 2006)

\subsubsection{Brand association}

According to Lassar et al. (1995), brand association refers to the relative strength of a consumer's positive feelings towards the brand. The interaction between customers and other relevant stakeholders has an influence on the brand equity of the firm. It has been argued by some researchers that when the customers' experience of a product or brand is positive, the brand becomes stronger and there is a positive reputation of the brand (Abimbola \& Vallaster, 2007). A study by Hamann et al. (2007) reveals that buyers often patronize and are also willing to pay premium prices for those products that are branded when they have a choice to select from products that fall into the same category. Buyers eventually identify with the brand and they also form some emotional bond with and sentimental attachment to the brand (Lassar et al., 1995). Consumers use the name of the brand to make inferences about the quality of a product they are not familiar with mainly because the brand name tends to build a reputation of the product as a result of the associations it has by virtue of its name and the utility or value of the product (Lassar et al., 1995). Some researchers (Simmons, 2007) explain that a brand evokes in the mind of customers a certain presence, personality and product or service performance. The associations can be either a functional consequence or a symbolic meaning (O’Loughlin \& Szmigin, 2005). According to Balmer and Gray (2003) buyers are usually persuaded to believe in some perceived cordiality associated with a particular brand. Hence, consumers tend to consume the brand and associate themselves with the brand to identify who they are, who they wish to be and/or how they wish to be seen. Brands become competitive in the marketplace as a result of the associations and behaviour of consumers towards them. Simply put, buyers tend to develop relationship with brands and such a relationship substitutes for human interaction between the firm and its customers. According to Delgado-Ballaster and Munuera-Aleman (2005), this relationship is known as relational market based brand equity. 


\subsubsection{Brand loyalty}

When a customer is loyal to a product or a brand, they consider it as their first option or choice and they are not influenced or affected by the strategies that are employed by competitors to lure them or get their attention (Tong \& Hawley, 2009).

Unlike the other antecedents of brand equity, brand loyalty develops from actual buying and usage of the product or brand (Baldauf et al., 2003). It is often indicated by the favourable attitude of consumers towards a brand, demonstrated by repeated purchase of the brand over time (Urde, 1994).

Brand equity is influenced by the subjective evaluation of any direct (e.g. trial, usage) and indirect contact (e.g. advertising, word of mouth) with the brand (Delgado-Ballaster \& Munuera-Aleman, 2005; Keller, 1993). Consequently, in order to achieve brand equity, it is important for firms to develop marketing strategies that not win only customers but also build trust and loyalty. Brand loyalty is an important characteristic of brands with high equity (Atilgan et al., 2005; Tong \& Hawley, 2009; Aaker, 1991). When a firm succeeds in building loyalty in the marketplace for its products and services, it leads to certain marketing advantages. The marketing advantages include price premiums, market share and greater trade leverage and reduced marketing costs (Delgado-Ballaster \& Munuera-Aleman, 2005)

\subsection{Concept of Internal Branding}

The service and corporate branding literature has recognised that staff are influential on customers and other stakeholders' brand perceptions through their role in delivering both functional (what are delivered) and emotional (how they are delivered) values (de Chernatony, 2002). When they are aligned with the brand values, a corporate (service) brand could achieve a sustainable competitive advantage (Pringle \& Thompson, 2001). Therefore, internal branding is argued as having the attainment of competitive advantage through people as its core objective, which is difficult to be replicated (Jacobs, 2003). This is then pertinent to the concern revolving around the heterogeneous quality of a service brand. On one hand, the intangible nature of service brands highlights the importance of brand promise fulfilment. As it is difficult to evaluate service brand quality, customers encounter perceived risks during a buying decision process. Dawar and Parker (1994) suggest that a brand needs to become a risk-reducing device. To achieve this, the brand promise needs to be delivered at every service encounter. On the other hand, the simultaneity of the production and consumption processes suggests the presence of consumers and service providers, which is further related to heterogeneity. Similarly, the corporate branding concept suggests numerous points of contact that stakeholders have with the brands (King, 1991). To ensure consistency of the brand experience across stakeholder groups, staff need to be enabled to understand their brand's values. Consequently, they will appreciate their roles and their commitment to delivering the brand promise will increase (Heskett, 1987). As such, Cleaver (1999) places an emphasis on internal issues to ensure staff's appreciation of the brand promise and use brand's values to guide their behaviours.

Internal branding has been proposed to promote the brand inside an organisation, namely to employees (Ahmed et al., 2003). Recent studies (Aurand et al., 2005; Burmann \& Zeplin, 2005) support that internal branding enables employees to deliver the brand promise during service 
encounters because it engenders a shared understanding of a brand across the entire organisation. In short, internal branding is argued to be instrumental in influencing employees' attitudes and shaping their behaviours to be aligned with a brand, by creating employees' understanding of brand values and engaging them in living brand reality (de Chernatony \& Segal-Horn, 2001; Drake et al., 2005; Kotter \& Heskett, 1992; Thomson et al., 1999).

\subsection{University brand equity}

Pinar, Trapp, Girard and Boyt, (2013), indicated that, Ivy (2008) identifies seven distinct factors that students find important in the selection of a university business school. In order of importance, with most important first, the factors are the program (choice of majors, electives), prominence (reputation), price (tuition), prospectus (communication through direct mail), people (interactions with faculty, staff, and other students), promotion (publicity and e-media), and premiums (mixture of various offerings). Other studies have focused on the importance of facilities (Price et al., 2003), the importance of emphasizing people (i.e. faculty, staff, other students, community) and processes (logistics of the service delivery) in the marketing of services (Cowell, 1982; Nicholls et al., 1995), and the tight linkage of positioning to the concept of branding (Nicholls et al., 1995). With respect to brand positioning, the prior research (Gatfield et al., 1999; Gray et al., 2003; Mazzarol, 1998) has identified academic instruction and learning environment, campus life, reputation, and career prospects for graduates as being the most salient dimensions in higher education. $\mathrm{Ng}$ and Forbes (2009) assert that the focal point of university branding is the learning experience as a part of core value-creation. Therefore, brand equity dimensions should be measuring the significance of the core value creation of learning experience.

\subsection{Brand equity and competitiveness}

According to Porter (1995), the competitiveness of firms is as a result of the value the firm is able to create for its customers at a reasonable cost compared to competitors. The intensity of competition in many industries has compelled firms to seek for new sources of competitive advantage from their available resources (Abimbola \& Kocak, 2007). The assertion by Porter (1995) is strengthened by Keller (1993), who also indicated that firms endeavour to gain a sustained competitive advantage so as to earn profits in both the short and long terms. The competitiveness of firms results from their ability to utilize efficiently resources and capabilities such as organisational processes and skills, knowledge and information as well as the skills of management (Asamoah, 2010). In studies by Farquhar (1989) and Wood (2000) it was found that the competitive advantage of firms with a high level of brand equity is that it provides them with an opportunity to succeed in extending their brand so as to stay resilient in the face of competition and pressures from the barriers to competitive entry, in addition to sales (Farquhar, 1989), profitability (Baldauf et al., 2003) and market share (Lassar et al., 1995).

A key strategy in marketing that achieves market performance and competitiveness of a firm is the creation of brand equity (Runyan \& Huddleston, 2006). However, there has been limited study on the relationship between the brand equity constructs and the market performance of firms. Baldauf et al. (2003) indicate that brand equity contributes directly to the enhancement of value to customers, in that it provides information and serves as a source of confidence and 
satisfaction of usage. Consequently, it enhances the firm's competitiveness, effectiveness and efficiency of its marketing programs, trade leverage, brand extension and ultimately the firms' profit margins. Brands serve as a source of reassurance to customers about the quality of the attributes of a product. A firm that is able to build a high level of equity for its brands will be able to leverage on it to launch new products as well as use it as cues for customers to repurchase the a product/brand (Hoek et al., 2003; Baldauf et al., 2003).

Furthermore, Leiser (2004) explains that there are many factors that influence the success of a brand when it is extended into new product categories or markets; notable among them is brand credibility. Apart from the service that is delivered, the stature and imagery of the brand is also sold to people who by the brand (O'Loughlin \& Szmigin, 2005). Also, when there is a higher level of brand association, there is a higher tendency for brand extension to become relevant to customers. Furthermore, brand awareness generates a high level of purchase, mainly because consumers are likely to buy those brands they are familiar with; hence, the firm's profitability and sales are enhanced (Baldauf et al., 2003). Research in the past has shown that when there is a high level of brand loyalty, sales are enhanced and there is growth in the firm's operations and performance. This is mainly because loyal buyers are less likely to be susceptible to price competition and they are less likely to switch brands (Hoek et al., 2003). The above argument is strengthened by research conducted by Kuczmarski \& Associates, which revealed a 72 per cent premium for their brand over its closest competitor (Leiser, 2004).

\subsection{Brand performance (bp)}

Brand performance refers to how successful a brand is in the market. It intends to measure the strategic achievements of a brand. As a result, economic measures are inappropriate for this construct. Brand awareness, reputation, and loyalty were suggested as important performance of a brand (Chaudhuri, 2002; Chaudhuri \& Holbrook, 2001; Reid, 2002; Wong \& Merrilees, 2007; Zeithaml, 1988). Since brand awareness and loyalty have been discussed in the above literature, reputation is presented. Balmer and Fombrun and van Riel (2004), reputation refers to value judgments about an organization's qualities, trustworthiness and reliability built up over time. This suggests that reputation is more durable than image, cannot be developed or altered as quickly (Markwick \& Fill, 1997), and requires nurturing through time (Bennett \& Kottasz, 2000). With hundreds of buying decisions to make every day, dozens of products to choose from and hundreds of promotional messages to come across, a customer most of the time relies on habit; that is they buy brands that have proved satisfactory in the past (Doyle, 1990).

\section{HYPOTHESIS}

The under listed hypotheses are formulated for the study.

- H1. There is a positive relationship between internal branding and the competitiveness of private universities;

- H2. There is a positive relationship between brand association and the performance of private universities;

- H3. There is a positive relationship between perceived quality and private universities performance; 
- H4. There is a positive relationship between brand loyalty and the performance of private universities;

- H5. There is a high predictive relationship between the antecedents of brand equity (brand loyalty, H5a; brand awareness, H5b; brand association, -H5c; perceived quality, H5d ) and the performance of private universities; and

- H6. When the level of brand loyalty is high, it results in a greater effect of brand equity on the performance of private universities.

It is observed from literature that brand loyalty is viewed as the dominant construct that would ensures greater performance and competitiveness of private universities. Therefore the study examines whether a higher level of brand loyalty will have a greater effect on brand equity and the performance of private universities hence H6. H4 looks at the loyalty and the performance of private universities and not both performance and brand equity.

\section{METHOD}

\subsection{Survey and measurement scales}

To achieve the objectives of this study and to test the testable hypotheses, a survey instrument was adapted from Pinar, Trapp, Girard, and Boyt (2014). On the measure of university brand equity which they developed the core value- creation brand equity scale items from the following sources: (i) brand awareness (Lassar et al., 1995; Aaker, 1996; Netemeyer et al., 2004; Buil et al., 2008; Tong \& Hawley, 2009), (ii) perceived quality (Aaker, 1991, 1996; Buil et al., 2008; Pappu et al., 2005, 2006; Yoo et al., 2000; Yoo \& Donthu, 2001; Tong \& Hawley, 2009), (iii) brand associations (Gray et al., 2003; Kim \& Kim, 2004; Pappu et al., 2006), and (iv) brand loyalty (Kim \& Kim, 2004; Yoo et al., 2000; Yoo \& Donthu, 2001). The study measure each item on a sevenpoint Likert-like scale of importance $(1=$ very unimportant; to 7 = very important). However, on the performance of private universities, the study used three (3) out of five (5) items used by Wong and Merrilees (2008) in measuring brand performance. The questions were modified to suit the purpose of measuring the performance of private universities. The questions were given to three professors of marketing who are knowledgeable about scale development and university branding to evaluate the intended meaning and clarity of the scale items. Based on their feedback, the study modified some of the scale items in order to improve the wording and clarity of meaning. Because the study's intention was to assess the performance of private universities in Ghana from the perspective of undergraduate students, who are the main focus and consumers of higher education, a pre-test was conducted with the target population and included students from different private universities and different levels. Thus, the pretests provided useful input for improving the survey items and in establishing face validity of the constructs (Churchill \& Iacobucci, 2005; Narver \& Slater, 1990).

\subsection{Sample and data collection}

The data for the study was collected from all private universities in Accra which have been accredited by the National Accreditation Board (NAB). The study selected all the nineteen (19) 
private universities in Accra accredited by the NAB. In order to have representation of students from all levels of classification and different all the private universities in Accra convenience sampling was purposefully used to targeted all undergraduate students in these private universities. Graduate level classes were not included in this study. In all, a total of 30 classes with varying sizes were involved which produced a total of 447 respondents used for the study. Though the private universities were nineteen (19) the questionnaires were administered to more than one class in some of the private universities. This is because the private universities some of the private universities had more business programs i.e. marketing, human resources, banking and finance etc. while others had only one or two business programs. This resulted in some of the universities having more than one questionnaire served on the business school of the university. These classes served as clusters where the survey was administered to all of the students in each class. Moreover, classes were selected in such a way that it minimized student overlap. However, to prevent duplications students were told not to complete the survey a second time. In order to make sure that the survey was completed properly, three marketing students of the researcher were trained to administer the surveys. These students helped in the entire data collection process and the data entering process. The data collection process lasted for four (4) weeks. This served as an opportunity for these students to learn how to conduct research which would enable them in writing their thesis/project work. These students read the survey and understood it and they helped in the collection of the data. This sampling process produced a total of 447 usable surveys.

\section{RESULTS}

Using the criterion of a Cronbach's a coefficient of greater than 0.6, the instruments proved to be satisfactory for gathering responses. Analysis in the form of regression and correlation between the variables and ANOVA were performed using the Statistical Package for Service Solution (SPSS) version 20. From the results of the analysis of variance (ANOVA), significant differences were found between female and male students of the private universities with regard to their perceptions of quality (significance $=0.029$ ). From the analysis, it was found that males (mean $=2.82$ ) recorded a higher score compared to females (mean $=2.71$ ). The findings on perceived quality between male and female students support previous studies of differences between categories of respondents in terms of sex (Muyimba, 2009). Hence, it can be said that there is a gap between the level of satisfaction and the quality that is offered by private universities in Ghana. Also, there was no significant difference among the respondents selected with regards to the nature of the students (either regular students or distance students), performance of private universities (significance $=0.531$ ) and brand equity (significance $=0.515$ ).

From Table 2, it is revealed that there is a relatively low level of brand equity. This is characterized by the low levels associated with brand loyalty and the perception of quality. The findings in Table 2 show that when the brand equity is small, there is a lower attraction of loyalty from customers because of their small size (Hoek et al., 2003). In Table 2, the sales growth is a ratio scaled variable. This is becasue all arithmetic operations are possible on a scale variable.. Also, there is an increase in the brand equity level when brand loyalty increases (Atilgan et al., 2005). From Table 3, it can be seen that the brand equity level is significant and positively related to 
the performance of private universities. Table 3 further reveals that the brand equity dimensions - i.e. perceived quality, brand awareness, brand loyalty and brand association - had a positive relationship with the performance of private universities. Hence, H1, H2, H3 and H4 were all confirmed. This finding confirms the assertion by Baldauf et al. (2003) that the antecedents of brand equity have a positive relationship with the performance of firms.

Tab. 1 - Summary Statistics of Respondents

\begin{tabular}{|c|c|c|c|}
\hline University & Male & Female & Total \\
\hline Central University College & 12 & 10 & 22 \\
\hline $\begin{array}{l}\text { Regent University College of Science and } \\
\text { Technology }\end{array}$ & 10 & 12 & 22 \\
\hline Islamic University College of Ghana & 8 & 9 & 17 \\
\hline Pentecost University College & 11 & 13 & 24 \\
\hline Ghana Christian University College & 11 & 13 & 24 \\
\hline Knutsford (University)College & 11 & 12 & 23 \\
\hline Trinity Theological Seminary & 13 & 12 & 25 \\
\hline Maranatha University College & 13 & 11 & 24 \\
\hline Data Link University College & 11 & 18 & 29 \\
\hline Valley View University & 12 & 11 & 23 \\
\hline Ashesi University & 13 & 10 & 23 \\
\hline Methodist University College of Ghana & 12 & 14 & 26 \\
\hline Wisconsin International University College & 12 & 17 & 29 \\
\hline $\begin{array}{l}\text { African University College of } \\
\text { Communication }\end{array}$ & 13 & 12 & 25 \\
\hline Ghana Telecom University College & 11 & 12 & 23 \\
\hline University College of Management Studies & 9 & 12 & 21 \\
\hline Jayee University College & 12 & 15 & 27 \\
\hline Zenith College & 11 & 10 & 21 \\
\hline Meridian University College & 8 & 11 & 19 \\
\hline Total & 213 & 234 & 447 \\
\hline
\end{tabular}

Source: Field Data, 2015

Tab. 2 - Brand Equity and performance of Private Universities in Ghana

\begin{tabular}{|l|c|c|c|c|}
\hline & Mean & $\begin{array}{c}\text { Standard } \\
\text { Deviation }\end{array}$ & Minimum & Maximum \\
\hline Brand Equity & 3.14 & 0.43 & 1.00 & 4.00 \\
\hline Brand Awareness & 3.01 & 0.37 & 1.32 & 3.79 \\
\hline Brand Associations
\end{tabular}




\begin{tabular}{|l|c|c|c|c|}
\hline Brand Quality & 2.48 & 0.43 & 1.32 & 5.17 \\
\hline Brand Loyalty & 2.48 & 0.41 & 1.72 & 6.08 \\
\hline Private University Performance \\
\hline New programmes success & 3.23 & 0.48 & 1.72 & 4.00 \\
\hline Performance in relation to competitors & 1.51 & 0.43 & 1.00 & 3.29 \\
\hline Sales Growth & 1.78 & 0.27 & 1.00 & 2.01 \\
\hline
\end{tabular}

Source: Field Data, 2015

Tab. 3 - The relationships between the brand equity dimensions and Private University Performance

\begin{tabular}{|l|c|c|c|c|c|c|}
\hline & 1 & 2 & 3 & 4 & 5 & 6 \\
\hline Brand Awareness -1 & 1.000 & & & & & \\
\hline Brand Associations - 2 & $0.245^{* *}$ & 1.000 & & & & \\
\hline Brand Quality - 3 & $0.321^{* *}$ & $0.316^{* *}$ & 1.000 & & & \\
\hline Brand Loyalty - 4 & $0.164^{* *}$ & $0.314^{*}$ & $0.184^{* *}$ & 1.000 & & \\
\hline Brand Equity - 5 & $0.391^{* *}$ & $0.190^{* *}$ & $0.423^{* *}$ & $0.231^{* *}$ & 1.000 & \\
\hline $\begin{array}{l}\text { Private University } \\
\text { Performance - 6 }\end{array}$ & $0.212^{* *}$ & $0.244^{* *}$ & $0.231^{* *}$ & $0.130^{*}$ & $0.208^{* *}$ & 1.000 \\
\hline
\end{tabular}

Source: Field Data, 2015

Note: $*$ Correlation is significant at the 0.05 level (two-tailed); ${ }^{* *}$ correlation is significant at the 0.01 level (two-tailed)

Tab. 4 - Multiple Regression Model of Brand Equity and Private University Performance

\begin{tabular}{|l|c|c|c|c|c|}
\hline \multirow{2}{*}{ Model } & \multicolumn{2}{|c|}{$\begin{array}{c}\text { Un-standardized } \\
\text { coefficients }\end{array}$} & $\begin{array}{c}\text { Standardized } \\
\text { coefficients }\end{array}$ & \multirow{2}{*}{$\mathrm{t}$} & \multirow{2}{*}{ Significance } \\
\cline { 2 - 4 } & $\mathrm{B}$ & $\mathrm{SE}$ & Beta & & \\
\hline (Constant) & 1.011 & 0.233 & & 3.102 & 0.000 \\
\hline Brand loyalty & 0.229 & 0.132 & 0.221 & 2.314 & 0.021 \\
\hline Perceived quality & 0.004 & 0.083 & 0.003 & 0.205 & 0.000 \\
\hline Brand awareness & 0.039 & 0.073 & 0.031 & 0.751 & 0.312 \\
\hline Brand association & 0.202 & 0.057 & 0.184 & 3.329 & 0.721 \\
\hline
\end{tabular}

Source: Field Data, 2015

Table 4 presents the multiple regression results of the brand equity constructs and Private University performance. Private University performance was used as the dependent variable, and it was found that the brand equity constructs predict $26.7 \%$ of Private University performance variance, with an adjusted R2 of 0.213 and an R2 of 0.301 . The F change was 19.96 with a significant $\mathrm{F}$ change of 0.000 . It was further revealed that there is a contribution of $34.9 \%$ of brand loyalty and $17.8 \%$ of brand association, which represents a significant change in the performance of Private Universities; hence, both $\mathrm{H} 5 \mathrm{a}$ and $\mathrm{H} 5 \mathrm{c}$ were confirmed. This means that both brand awareness and perceived quality were not found to be significant in predicting the performance 
of Private Universities; hence, H5b and H5d were not supported. The results from the analysis also revealed that when brand loyalty is high, then there is a stronger effect of brand equity on the performance of private universities; therefore, H6 was supported.

The results in Table 4 show an inconsistency with past research by Baldauf et al. (2003). Baldauf et al. (2003) found that the various antecedents of brand equity together significantly predict the performance of firms, which is inconsistent with the findings in this study. One explanation for this could be due to the size of Private Universities compared to that of Public Universities; in the two groups, the approach and focus of brand building differs significantly (Abimbola \& Kocak, 2007). Other factors for the difference other than the size of the firm can be attributed to time, resource constraints and marketing knowhow (Krake, 2005). Some researchers, such as $\mathrm{Na}$ and Marshall (2005), explain that the differences could also be attributed to factors such as cultural values in countries, and the level of technological and infrastructural differences. Also, Atilgan et al. (2005) explain that the differences are not surprising, because among all of the antecedents of brand equity, brand loyalty represents the core dimension; hence, it has a direct and significant influence on brand equity.

\section{CONCLUSION}

The findings of the study revealed that the performance of Private Universities located in the Greater Accra Region of Ghana and brand equity are high when there is high brand loyalty among students. The role of internal brand management in the performance of Universities in general and Private Universities in particular cannot be over-emphasised. The interest for internal branding throughout the Universities sampled is a very important factor, initiated by an active role of the University authorities. In the development and implementation of internal branding, the creativity and initiation of the brand management team is indispensable. Building strong brand equity takes energy, time, and is a complex and demanding process. Although financial resources are an important component in internal branding building, it is recommended that private universities explore and make full use of their unique features; wisely using resources and strengthening their core values and mandate will build up their brands greatly. Though this study is limited to Ghana, other similar countries where there are private universities could take a lesson from this study about the management of internal branding in the performance of private universities.

It is also recommended that the board and brand management team of private universities devote much of their attention to building brand loyalty among students, irrespective of the category in which the students fall. Strategies must be developed for brand associations as they are a prerequisite for the growth and continuous survival of any businesses establishment in highly competitive markets. Also, the study indicates that brand equity and its antecedents (perceived quality, brand awareness, brand loyalty and brand associations) are separately and positively related to the performance of private universities. In statistical terms, perceived quality and brand awareness are not significant predictors of the performance of private universities. However, brand loyalty and brand associations do have a significant effect on the performance of private universities. Also, the study found that, when there is a high level of loyalty towards a brand, 
brand equity tends to have a greater effect on the performance of private universities. The study is limited to only private universities in the Greater Accra region of Ghana. Future studies could go further into comparing the extent of prediction by the antecedents of brand equity in both private universities and public universities. Also, it would be useful to study the level of control and the major decision-making factors when deciding on the focus of internal brand building in both private and public universities. Furthermore, future studies could focus on variations across industries with regard to the impact of internal branding equity on the performance of universities. Institutions other than the educational sector such as services, manufacturing and trade could be investigated to find the predictive power of the antecedents of brand equity.

\section{References}

1. Aaker, D. A. (1996). Measuring brand equity across products and markets. California management review, 38(3), 102-120.

2. Aaker, D.A. (1991). Managing Brand Equity. Free Press, New York.

3. Abimbola, T., \& Kocak, A. (2007). Brand, organization identity and reputation: SMEs as expressive organizations: A resources-based perspective. Qualitative Market Research: An International Journal, 10(4), 416-430.http://dx.doi.org/10.1108/13522750710819748

4. Abimbola, T., \& Vallaster, C. (2007). Brand, organisational identity and reputation in SMEs: an overview. Qualitative market research: an international Journal, 10(4), 341-348. http:// dx.doi.org/10.1108/13522750710819685

5. Ahmed, P. K., Rafiq, M., \& Saad, N. M. (2003). Internal marketing and the mediating role of organisational competencies. European Journal of Marketing, 37(9), 1221-1241. http://dx.doi. org/10.1108/03090560310486960

6. Aurand, T. W., Gorchels, L., \& Bishop, T. R. (2005). Human resource management's role in internal branding: an opportunity for cross-functional brand message synergy. Journal of Product \& Brand Management, 14(3), 163-169. http://dx.doi.org/10.1108/10610420510601030

7. Baldauf, A., Cravens, K. S., \& Binder, G. (2003). Performance consequences of brand equity management: evidence from organizations in the value chain. Journal of product \& brand management, 12(4), 220-236. http://dx.doi.org/10.1108/10610420310485032

8. Balmer, J. M., \& Gray, E. R. (2003). Corporate brands: what are they? What of them?. European journal of marketing, 37(7/8), 972-997. http://dx.doi.org/10.1108/030905603104776 27

9. Bennett, R., \& Kottasz, R. (2000). Emergency fund-raising for disaster relief. Disaster Prevention and Management: An International Journal, 9(5), 352-360. http://dx.doi.org/10.1108/0 9653560010361393

10. Berry, L. L. (2000). Cultivating service brand equity. Journal of the Academy of marketing Science, 28(1), 128-137. http://dx.doi.org/10.1177/0092070300281012

11. Buil, I., de Chernatony, L., \& Martinez, E. (2008). A cross-national validation of the consumer-based brand equity scale. Journal of Product \& Brand Management, 17(6), 384-392. http://dx.doi.org/10.1108/10610420810904121 
12. Burmann, C., \& Zeplin, S. (2005). Building brand commitment: A behavioural approach to internal brand management. Journal of brand management, 12(4), 279-300. doi:10.1057/palgrave. bm. 2540223

13. Churchill, G.A. Jr., \& Iacobucci, D. (2005), Marketing Research: Methodological Foundations, 9th ed., Thomson/South-Western, Mason, OH.

14. Dawar, N., \& Parker, P. (1994). Marketing universals: Consumers' use of brand name, price, physical appearance, and retailer reputation as signals of product quality. The Journal of Marketing, 81-95.

15. Delgado-Ballester, E., \& Luis Munuera-Alemán, J. (2005). Does brand trust matter to brand equity?. Journal of product \& brand management, 14(3), 187-196. http://dx.doi.org/10.1108 /10610420510601058

16. Du Preez, R., \& Bendixen, M. T. (2015). The impact of internal brand management on employee job satisfaction, brand commitment and intention to stay. International Journal of Bank Marketing, 33(1), 78-91.

17. Fombrun, C. J., \& Van Riel, C. B. (2004). Fame \& fortune: How successful companies build winning reputations. FT Press.

18. Gummesson, E. (1987). Using internal marketing to develop a new culture-the case of Ericsson quality. Journal of Business \& Industrial Marketing, 2(3), 23-28.

19. Jacobs, R. (2003). Turn employees into brand ambassadors. Bank Marketing, 35(3), 22-27.

20. Keller, K. L. (1993). Conceptualizing, measuring, and managing customer-based brand equity. The Journal of Marketing, 1-22.

21. Keller, K. L. (2003). Strategic brand management (Vol. 11998). New Jersey: Prentice Hall.

22. Keller, K. L., \& Lehmann, D. R. (2003). How do brands create value?. Marketing Management, 12(3), 26-31.

23. Keller, K. L., \& Lehmann, D. R. (2006). Brands and branding: Research findings and future priorities. Marketing science, 25(6), 740-759. http://www.jstor.org/stable/40057218

24. Kim, W. G., \& Kim, H. B. (2004). Measuring customer-based restaurant brand equity. Cornell Hotel and Restaurant Administration Quarterly, 45(2), 115-131.

25. King, S. (1991). Brand-building in the 1990s. Journal of Marketing Management, 7(1), 3-13. doi:10.1080/0267257x.1991.9964136

26. Kotler, P., \& Armstrong, G. (2012). Principles of Marketing, 13th ed., Upper Saddle River, NJ: Prentice-Hall.

27. Kotler, P., \& Keller, K.L. (2006). Marketing Management, 12th ed., Upper Saddle River, NJ: Prentice-Hall.

28. Kotter, J., \& Heskett, J. (1992). Corporate Culture and Performance, New York: The Free Press.

29. Lassar, W., Mittal, B., \& Sharma, A. (1995). Measuring consumer-based brand equity. Journal of Consumer Marketing, 12(4), 11-19. http://dx.doi.org/10.1108/07363769510095270 
30. Lee, J.-S., \& Back, K.-J. (2010), Reexamination of attendee-based brand equity. Tourism Management, 31(3), 395-401. doi:10.1016/j.tourman.2009.04.006

31. Leiser, M. (2004). Understanding brands value: advancing brand equity tracking to brand equity management. Handbook of Business Strategy, 5(1), 216-222. http://dx.doi.org/10.1108/1 0775730410494189

32. Liao, N.N.H., \& Wu, T.C. (2009). The pivotal role of trust in customer loyalty: empirical research on the system integration market in Taiwan. The Business Review, 12 (2), 277-282.

33. Markwick, N., \& Fill, C. (1997). Towards a framework for managing corporate identity. European Journal of Marketing, 31 (5/6), 396-409. http://dx.doi.org/10.1108/eb060639

34. Mok, K. H. (1999). Education and the market place in Hong Kong and Mainland China. Higher Education, 37(2), 133-158.

35. Morhart, F. M., Herzog, W., \& Tomczak, T. (2009). Brand-specific leadership: Turning employees into brand champions. Journal of Marketing, 73(5), 122-142.

36. Netemeyer, R. G., Krishnan, B., Pullig, C., Wang, G., Yagci, M., Dean, D., ... \& Wirth, F. (2004). Developing and validating measures of facets of customer-based brand equity. Journal of Business Research, 57(2), 209-224. doi:10.1016/S0148-2963(01)00303-4

37. O'Loughlin, D., \& Szmigin, I. (2005). Customer perspectives on the role and importance of branding in Irish retail financial services. International Journal of Bank Marketing, 23(1), 8 27.http://dx.doi.org/10.1108/02652320510577348

38. Pappu, R., Quester, P. G., \& Cooksey, R. W. (2005). Consumer-based brand equity: improving the measurement-empirical evidence. Journal of Product \& Brand Management, 14(3), 143-154. http://dx.doi.org/10.1108/10610420510601012

39. Pappu, R., Quester, P. G., \& Cooksey, R. W. (2006). Consumer-based brand equity and country-of-origin relationships: Some empirical evidence. European Journal of marketing, 40(5/6), 696-717. http://dx.doi.org/10.1108/03090560610657903

40. Pike, S., Bianchi, C., Kerr, G., \& Patti, C. (2010). Consumer-based brand equity for Australia as a long-haul tourism destination in an emerging market. International marketing review, 27(4), 434-449. http://dx.doi.org/10.1108/02651331011058590

41. Pina, J. M., Martinez, E., De Chernatony, L., \& Drury, S. (2006). The effect of service brand extensions on corporate image: an empirical model. European Journal of Marketing, 40(1/2), 174-197.http://dx.doi.org/10.1108/03090560610637374

42. Pinar, M., Trapp, P., Girard, T., \& E. Boyt, T. (2014). University brand equity: an empirical investigation of its dimensions. International Journal of Educational Management, 28(6), 616-634. http://dx.doi.org/10.1108/IJEM-04-2013-0051

43. Pitta, D. A., \& Prevel Katsanis, L. (1995). Understanding brand equity for successful brand extension. Journal of consumer marketing, 12(4), 51-64. http://dx.doi.org/10.1108/07363769510 095306

44. Price, I. F., Matzdorf, F., Smith, L., \& Agahi, H. (2003). The impact of facilities on student choice of university. Facilities, 21(10), 212-222.

45. Pringle, H., \& Thompson, M. (2001). Chichester: Brand Spirit, Wiley. 
46. Punjaisri, K., \& Wilson, A. (2007). The role of internal branding in the delivery of employee brand promise. Journal of Brand Management, 15(1), 57-70. doi:10.1057/palgrave. bm. 2550110 .

47. Reichheld, F. (2001). Loyalty Rules. Harvard Business School Press. Boston, MA.

48. Reichheld, F. (2006), The Ultimate Question, Harvard Business School Press, Boston, MA.

49. Selase Asamoah, E. (2014). Customer based brand equity (CBBE) and the competitive performance of SMEs in Ghana. Journal of Small Business and Enterprise Development, 21(1), 117131. http://dx.doi.org/10.1108/JSBED-10-2013-0154

50. Tong, X., \& Hawley, J. M. (2009). Measuring customer-based brand equity: empirical evidence from the sportswear market in China. Journal of Product \& Brand Management, 18(4), 262-271. http://dx.doi.org/10.1108/10610420910972783

51. Urde, M. (1994). Brand orientation-a strategy for survival. Journal of consumer marketing, 11(3), 18-32. http://dx.doi.org/10.1108/07363769410065445

52. Yoo, B., \& Donthu, N. (2001). Developing and validating a multidimensional consumerbased brand equity scale. Journal of business research, 52(1), 1-14.

53. Yoo, B., Donthu, N., \& Lee, S. (2000). An examination of selected marketing mix elements and brand equity. Journal of the academy of marketing science, 28(2), 195-211.

\section{Contact information}

Hayford Amegbe (MBA)

School of Business

Dominion University College

PMB CT 69 ,Cantonments

Accra, Ghana

e-mail:dansohay@yahoo.com,h.amegbe@duc.edu.gh 